\title{
TUMBLEWEEDS AND INDELICATE QUESTIONS
}

\section{A matter of honour.}

\section{BY JOHN P. MURPHY}

$\mathrm{I}$ was very careful to pay no attention to the gnarly, four-eyed alien head peering over my shoulder. Instead, I wiped down the bar and put the glasses into the sink - the work needs to get done, after all, and I sure wasn't slacking.

The only two customers left after the rush sat and watched me. I figured I wasn't going to be able to weasel out of answering their question, but I wasn't inclined to hurry myself, either. Besides, this bet of theirs was the first time they'd stopped arguing all night — I was enjoying the peace.

"C'mon, Sal," said the lady in the mechanic's overalls. "You're stalling."

"I ain't stalling," I protested. "I'm just trying to get my work done so's I can get out of here on time." I should have told her to buy something, but her being more drunk wouldn't help matters.

"It's a simple question," the mechanic said. "Did you kill that tumbleweed yourself or not?" She was talking about old Harry — the big hairy head with all the fangs that sat nestled in with the bottles up on the top shelf.

She'd been the one to bet I'd killed it. The other one, dressed like a lawyer, pretty much called me chicken. They wouldn't like the answer; they'd just argue more. But I figured that refusing wouldn't satisfy honour on the subject, and they'd just go back to bickering anyway.

"Well, sure you think it's a simple question," I said, giving old Harry a big theatrical wink, "but that ain't so."

The other customer shook her head. She sounded like a lawyer, too. "I hardly think that if Sal had killed a sentient being, she'd have proof of it sitting out for everyone to see."

"We-ell," I said. "I don't know about that. Silver City might be a happening town now with the new spaceport and all, but it used to be a bit of a wild place. Could be maybe I did shoot the old bastard, and just got, whatchacallit, grandmothered in."

"I knew it!" The mechanic grinned and slapped the bar.

\section{$\rightarrow$ NATURE.COM}

\section{Follow Futures:}

@ @NatureFutures

f go.nature.com/mtoodm

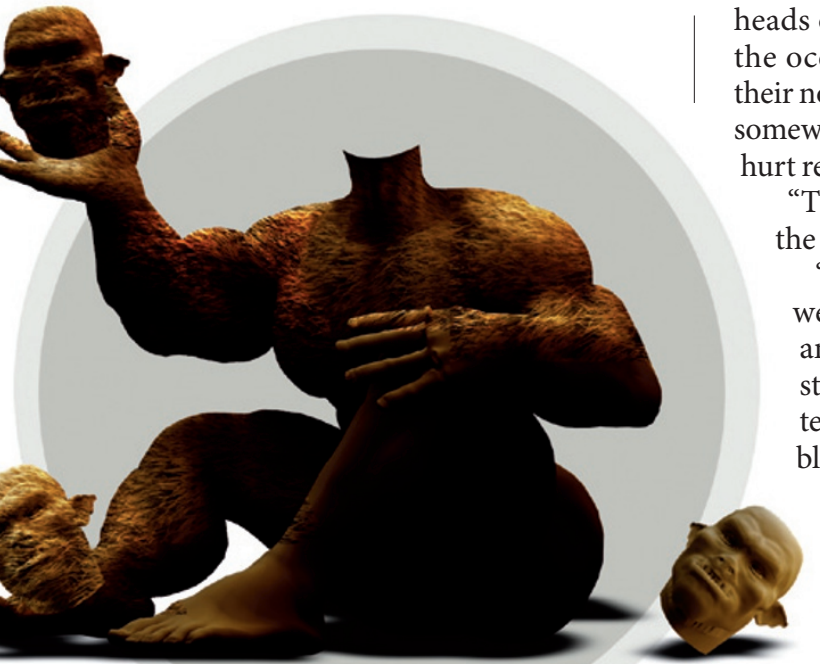

heads off. Times get lean, they wade into he ocean, then they pop their tops and their noggins float away to grow a new body somewhere nicer. Sometimes when they get urt real bad they do it too."

"That why the call them tumbleweeds," the mechanic said, "or coconut trolls."

"Anyway, things calmed down and we got to talking instead of fighting, and found out it was all a misunderstanding. Apologies all round, and we tended the wounded. One of the tumbleweeds pulled through - nice fella, comes in sometimes to shoot the shit - but the other, Harry, wasn't so lucky.

"We buried Suki according to her custom, but we had a problem with Harry. Harry's clan's death customs had rules, and we needed to know who killed him to figure out what to do with him. If I'd killed him, I was supposed to eat the ugly bugger. Otherwise, we was supposed to burn him so's Suki's ghost could eat him.

"But we lost track of their heads in the fight, see? We didn't know whether I killed Harry or winged his buddy."

The lawyer looked smug all of a sudden. "There's a loophole."

I gave her the stink eye, interrupting someone in the middle of her story like that, but she hardly noticed. "That's right, there's a loophole: when Suki and I've both croaked they can safely burn him and let us sort it out up there. So there the poor guy stays until I kick the bucket."

All three of us gave that ugly puss a good long stare.

"So!" I broke the silence. "Neither of you's right, but just so's there's no hard feelings, next round's on the house."

They finished their drinks in companionable silence and paid their tabs. If they left together, I wasn't paying no mind, just washing dishes.

"You're so full of shit, Sal." Harry snickered as he climbed off his shelf.

I just gave him a peck on the cheek and told him to hush..

John P. Murphy is an engineer and writer living in New Hampshire. He is a member of the SFWA, IEEE and Codex 